\title{
Viability of meyer lemon over sour orange rootstock
}

\author{
Syed Tanveer Shah ${ }^{1}$, Shahid Rahman ${ }^{1}$, Nadeem Khan ${ }^{1 *}$, Muhammad \\ Sajid ${ }^{1}$, Abdur Rab ${ }^{1}$, Noor ul Amin ${ }^{1}$, Saeed U1 Haq ${ }^{1}$, Said Rawan ${ }^{1}$, Shah \\ Faisal $^{1}$ and Rafiq Ahmad ${ }^{2}$ \\ 1. Department of Horticulture, The University of Agriculture Peshawar-Pakistan \\ 2. Department of SES, The University of Agriculture Peshawar-Pakistan \\ *Corresponding author's email: nadeemaup@yahoo.com \\ Citation \\ Syed Tanveer Shah, Shahid Rahman, Nadeem Khan, Muhammad Sajid, Abdur Rab, Noor ul Amin, Saeed Ul Haq, \\ Said Rawan, Shah Faisal and Rafiq Ahmad. Viability of meyer lemon over sour orange rootstock. Pure and Applied \\ Biology. Vol. 5, Issue 2, 2016, pp326-331. http://dx.doi.org/10.19045/bspab.2016.50042
}

\begin{tabular}{llll}
\hline \hline Received: 17/09/2015 & Revised: 21/03/2016 & Accepted: 29/03/2016 & Online First: 09/04/2016 \\
\hline
\end{tabular}

\section{Abstract}

The information pertaining the performance of Meyer lemon over citrus rootstocks is very limited. Fruit tree rootstocks have varying degrees of tree vigor and growth, salt and drought tolerance, resistance to pest and diseases and leaf mineral application. Sour orange rootstock is more favorable than other citrus rootstocks due to its resistance to gummosis, high flexibility to wide range of soil conditions, and the ability to produce high quality fruits. Therefore the present study was designed to investigate the Viability of Meyer lemon over sour orange rootstock, conducted at Government Fruit Nursery Farm, Jabban, Dargai Malakand Agency, an experiment was conducted during the year 2013. The experiment was laid out Completely Randomized Design (CRD) with one factor repeated three times. Meyer lemon was grafted on different dates $\left(1^{\text {st }}\right.$ May, $1^{\text {st }}$ June and $1^{\text {st }}$ July) on sour orange rootstock, grafting dates significantly affected all the growth attributes expect leaf area. Maximum scion diameter $(1 \mathrm{~cm})$, number of leaves plant ${ }^{-1}$ (20), survival percentage $(83 \%)$, scion length $(30 \mathrm{~cm})$ and minimum days to sprouting (17) was recorded in plants grafted on $1^{\text {st }}$ June. It is concluded from the present study that Meyer lemon should be grafted at 1 st June over sour orange rootstock for better results, hence recommended for the farmers of the agro-climatic condition of Malakand.

Key words: Viability; Meyer lemon; Sour orange; Rootstock; Timing

\section{Introduction}

Citrus belongs to family Rutaceae of flowering plants (Angiosperm). Sweet oranges are mostly grown in tropical and subtropical climates. In these regions oranges grove are found at an elevation of 450-750 $\mathrm{m}$ above sea level [1]. The Meyer lemon is a cross between a lemon and possibly an orange or a mandarin, and was named after Frank N. Meyer, who first discovered it in 1908. Meyer lemons have a much thinner rind, and often grown-up to a yellow-orange color. Meyer lemons are to some extent more frost-tolerant than other lemons [2]. Varies \& Dubois [3] observed that in grafted plants, vigor of the genotype used as a rootstock is transferred to the scion and thus influences growth and productivity. The use of vigorous and healthy rootstock is a key element that affects the quality and 
yield of citrus fruits. In the process of plants growth and development, photosynthetic substances are transfer from sources to sinks; therefore, rootstocks are very important as a source. Fruit tree rootstocks have varying degrees of tree vigor and growth, salt and/or drought tolerance, resistance to pest and diseases and leaf mineral application [4]. Sour orange rootstock is more favorable than other citrus rootstocks due to its resistance to gummosis, high flexibility to wide range of soil conditions, and the ability to produce high quality fruits [5]. For choosing a suitable rootstock, its adaptability to the soil environment and the interactive effects with the scion cultivar has to be considered. The rootstocks significantly influence on the morphological and horticultural characteristics of the scion cultivar. Many horticultural characters such as tree growth, yield and fruit size, weight, rind thickness, juice content and total soluble solids of fruit are influenced by rootstocks [6]. Their seeds are sown in September to make it protected from frost which is then ready for grafting in 6-12 months. A healthy rootstock is already has an established and strong root system, on to which a cutting or bud from another plant is grafted. In some cases, such as vines of grapes and other berries, cutting may be used for rootstock, the roots being established in nursery condition before planting them out [7]. In the case of citrus trees of one variety, the rootstock is selected for its hardiness and the other variety, the scion is selected for its high quality fruits [8]. The information pertaining to the effects of rootstock on the performance of Meyer lemon is limited. The rootstocks used in this study were chosen due to the earlier or promising performance in other areas and with other citrus cultivars. Thus, this research was carried out to evaluate the compatibility of Meyer Lemon over sour orange rootstock and find out the effect to sour orange on the growth of Meyer lemon.

\section{Materials and methods}

The experiment was laid down in Randomized Complete Block Design (RCBD) with one factor replicated three times. Meyer lemon was grafted on 2 years old sour orange rootstock having $3 \mathrm{~cm}$ in diameter on different dates i.e. $1^{\text {st }}$ May, $1^{\text {st }}$ June and $1^{\text {st }}$ July. Myer lemon grafts were collected from farmer's orchard in Fruit Nursery Farm, Jabban, Dargai Malakand. The grafts were cut in slanting position using sharp knife and were kept in gunny bags. The grafts were grafted on middle stem of orange plants $90 \mathrm{~cm}$ above the ground by side grafting method. T cut was made to remove the bark; $2 \mathrm{~cm}$ in length and $3 \mathrm{~cm}$ in diameter so that the cambium gets visible. The grafts were then placed and rapped with transparent plastic sheet carefully. All the other horticultural operations (Fertilization, irrigation, weeding, hoeing, maturing, pesticides use for diseases and pest attack etc) were kept constant. The following growth attributes were studied during the course of the experiment.

\section{Days to sprouting}

Days to sprouting were recorded from the date of sowing to the date when $50 \%$ sprouting appear in each replication.

\section{Scion length $(\mathrm{cm})$}

Scion length of 5 randomly selected plants from each treatment in each replication was recorded from base to top of the graft with the help of measuring tape and then average was worked out.

\section{Scion diameter $(\mathbf{c m})$}

Diameter of plant above graft union of randomly 5 selected plants for all treatment in each replication was measured with help of vernier caliper and then average was calculated.

\section{Number of leaves plant ${ }^{-1}$}

Number of leaves plant ${ }^{-1}$ was counted by randomly selecting 5 plants from each 
treatment in replication and then average was worked out.

\section{Leaf area $\left(\mathrm{cm}^{2}\right)$}

The leaf area was determined with help of Leaf area machine of five randomly selected leaves from each treatment and average was calculated.

\section{Survival percentage}

Percent plant survival from each treatment in each replication was calculated by following formula.

Survival $\%=$ Number of plant survived $\times 100$

\section{Statistical analysis}

Total number of grafted plants

The data recorded on different attributes were analyzed by using the statistical computer software, MSTATC (Michigan State University, USA). Analysis of variance (ANOVA) and LSD test were performed to find out the differences among treatments and interaction. The mean values for difference were compared by using least Significant Difference Test [9].

\section{Results and discussion}

\section{Days to sprouting}

Days to sprouting of Meyer lemon were significantly affected by different time of grafting over sour orange rootstock (Table 1). Maximum days to sprouting (21) were observed in Meyer lemon plant grafted on $1^{\text {st }}$ of July, 2013, while the minimum days to sprouting (17) were observed in plants grafted on $1^{\text {st }}$ June, 2013. Grafts needs moderate temperature and high humidity and these factors were significant during the experiment. In the first week of June there is moderate temperature and more humidity and later on the humidity decreases which effects the growth of the grafting. This could be credited to their well developed and strong tissues that survived the sizzling sun and high temperatures in the grafting period unlike the tender tissues in the juvenile scions. In vegetative propagation, temperature is a requirement as it induces cell division, shoot elongation, photosynthesis. All these factors are very essential for the growth or shooting of grafted material. The findings are in agreement with [10] who reported that air temperature $\left(30.4\right.$ to $36.4^{\circ} \mathrm{C}$ ) and relative humidity ( 80 to $85 \%$ ) determine the success of grafting propagation on cashew nut. These results support the findings of previous studies which concluded that the temperature plays a significant role with respect to early growth and development of walnut [11] and citrus [12] during grafting.

\section{Scion length $(\mathrm{cm})$}

The data for scion length $(\mathrm{cm})$ shows that different time of grafting significantly influenced the scion length $(\mathrm{cm})$ of lemon plant (Table 1). The plants grafted on $1^{\text {st }}$ June produced highest scion length $(30 \mathrm{~cm})$ while the lowest scion length $(25.66 \mathrm{~cm})$ recorded in plants grafted at $1^{\text {st }} \mathrm{July}, 2013$. It has been reported that grafting promote vegetative growth at different time depending on rootstock characteristics. Promoted vigor and vegetative growth could be explained by obtainable resistance to soil borne diseases [13], increased water and plant nutrition uptake [14], increased endogenous hormone production [15], tolerance to low soil temperature [16] and salinity tolerance in the rootstocks [14], thus all these factors contribute to the enhance in scion length. It might also be due to the fact that, scion length is certainly associated with sprouting. As the sprouting get early so it ultimately resulted in increased scion length. The present results are in close conformity with one of the study in which successful grafting between kinnow plant rough lemons was done and observed better vegetative performance of kinnow over rough lemon [17].

\section{Scion diameter $(\mathbf{c m})$}

Statistical analysis of variance showed that different grafting dates had a significant effect on scion diameter $(\mathrm{cm})$ of lemon plants (Table 1). However, comparing the 
means of scion diameter, it is clear that that maximum scion diameter $(1 \mathrm{~cm})$ was recorded in plants grafted at $1^{\text {st }}$ June 2013 while minimum scion diameter $(0.56 \mathrm{~cm})$ was observed in plants grafted at $1^{\text {st }}$ July 2013. The improvements in these characters might be due to enhancement in vegetative growth which is expected to be responsible for more buildup of photosynthetic, hence resulted in giving maximum value in these characters. These findings are in close similarity with the findings of $[18,19]$ who reported that buildup of photosynthetic in scion determine the maximum scion diameter in chrysanthemum.

\section{Leaf area $\left(\mathrm{cm}^{2}\right)$}

Data regarding leaf area $(\mathrm{cm} 2)$ shows that different time of grafting non-significant effect on the leaf area $(\mathrm{cm} 2)$ of Meyer lemon grafting over sour orange rootstock (Table 1). However, Comparing the means of leaf area, it is clear from the mean table that wider leaves $\left(18.33 \mathrm{~cm}^{2}\right)$ were recorded in plants grafted at $1^{\text {st }}$ May, 2013, while the minimum leaf area $\left(16 \mathrm{~cm}^{2}\right)$ was recorded in plants grafted at $1^{\text {st }}$ July 2013.

\section{Number of leaves plant ${ }^{-1}$}

The data regarding number of leaves plant $^{-1}$ were significantly affected by different time of grafting of Meyer lemon plant (Table 1). Maximum number of leaves plant ${ }^{-1}$ (20) was observed in plants grafted at $1^{\text {st }}$ of June and minimum number of leaves plant ${ }^{-1}$ (16) was observed in plants grafted on $1^{\text {st }}$ July 2013. The data regarding number of leaves plant $^{-1}$ was found significant because in this experiment most fresh scions were used that were rich in photosynthesis. Number of leaves produced by a plant is directly proportional to the photosynthesis produced [20]. Young seedlings have a very high rate of photosynthesis as the number of leaves in young seedlings is increasing time by time so high amount of photosynthesis are build up in it. Maximum number of leaves resulted in higher rates of photosynthesis that ensured an increase in carbohydrate production [21], hence all these factors contribute to the increase in number of leaves. It might also be due to the fact that, number of leaves is positively correlated with scion length. As the length of scion get increased so it ultimately resulted in increased number of leaves.

\section{Survival percentage $(\%)$}

Data recording survival percentage of Meyer lemon plant shows a significant affect grafting at different time on sour orange rootstock (Table 1). By comparing the means for survival of grafted plants, we observed that most of plants survived $(83 \%)$ grafted at 1 st of June and minimum number of plants that survived $(46.66 \%)$ was observed at $1^{\text {st }}$ of July which was statistically similar with mean number of plant survived $(60 \%)$ grafted at $1^{\text {st }}$ of May 2013. [22] Reported that decomposed organic material improved soil fertility by increasing soil aeration, water holding capacity and water infiltration and lower surface crusting. The mechanisms involved in these different responses are related to growth rate before grafting, tissue age, climatic conditions, rootstock leaf area, wetness of cut area, cut surface in contact area, pressure between cut area and number of vascular bundles in the same area [23, 24]. So, lower temperature in 2nd stage caused significant effect on the callus formation in the graft portion and increased graft take success. Similarly, it was hypothesized that early and delayed incompatibility might be involved with different genes. These findings are in close similarity with the findings of [25], who reported that compatibility is dependent on the presence of a particular factor or absence of the factors in both rootstock and scion in rose. 
Table 1. Days to sprouting, Scion diameter $(\mathrm{cm})$, Scion length $(\mathrm{cm})$, Leaf area $\left(\mathrm{cm}^{2}\right)$, Number of leaves plant ${ }^{-1}$ and Survival percentage as affected by different time of grafting Meyer lemon over Sour orange rootstock

\begin{tabular}{|c|c|c|c|c|c|c|}
\hline \multirow{2}{*}{$\begin{array}{l}\text { Grafting } \\
\text { dates }\end{array}$} & \multicolumn{6}{|c|}{ Parameters } \\
\hline & DTS & $\mathrm{SL}(\mathrm{cm})$ & $\mathrm{SD}(\mathbf{c m})$ & $\mathrm{LA}\left(\mathrm{cm}^{2}\right)$ & NLP & GS (\%) \\
\hline $\begin{array}{c}1^{\text {st }} \text { May, } \\
2013\end{array}$ & $19 \mathrm{~b}$ & $27.66 \mathrm{~b}$ & $0.83 \mathrm{~b}$ & $18.33 \mathrm{a}$ & $18 \mathrm{~b}$ & $60 \mathrm{~b}$ \\
\hline $\begin{array}{c}1^{\text {st }} \text { June, } \\
2013\end{array}$ & $17 \mathrm{c}$ & $30 \mathrm{a}$ & $1.0 \mathrm{a}$ & $17.22 \mathrm{a}$ & $20 \mathrm{a}$ & $83 a$ \\
\hline $\begin{array}{c}1^{\text {st }} \text { July, } \\
2013\end{array}$ & $21 \mathrm{a}$ & $25.66 \mathrm{c}$ & $0.56 \mathrm{c}$ & $16 \mathrm{a}$ & $16 \mathrm{c}$ & $46.66 \mathrm{~b}$ \\
\hline $\begin{array}{c}\text { LSD } \\
(\mathrm{P}<0.05)\end{array}$ & 1.30 & 1.19 & 0.09 & ns & 1.24 & 18.51 \\
\hline
\end{tabular}

DTS: Days to sprouting, SL: Scion length, SD: Scion Diameter, LA: Leaf area, NLP: Number of leaves plant ${ }^{-1}$, GS: Graft survival.

Means followed by similar letters are statistically non-significant / similar at $5 \%$ level of significance.

\section{Conclusion and recommendations}

Maximum scion diameter, number of leaves plant $^{-1}$, survival percentage, scion length and minimum days to sprouting was recorded at $1^{\text {st }}$ June of grafting followed by $1^{\text {st }}$ May while $1^{\text {st }}$ July resulted in poor performance of Meyer lemon over sour orange rootstock. Hence, it is concluded from the present study that Myer lemon should be grafted in the $1^{\text {st }}$ week of June over sour orange rootstock for obtaining better growth and yield attributes of Meyer lemon and hence recommended for the farmers of Malakand region.

\section{Authors' contributions}

Conceived and designed the experiments: ST Shah, Performed the experiments: S Rahman, M Sajid \& A Rab, Analyzed the data: N Amin \& R Ahmad, Contributed reagents/materials/analysis tools: $\mathrm{S}$ Faisal, $\mathrm{S}$ Rawan \& SU Haq, Wrote the paper: N Khan.

\section{References}

1. Nafees A, Rahman KA, Liaqat A \& Bhatti IA (2008). Studies on grafting methods of low seeded kinnow on rough lemon. American-Eurasian. $J$ Agric Envir Sci 3(3): 339-342.

2. Morton J (1987). Fruits: Lemon of warm climates Miami. Pp. 160-168 http://www.hort.purdue.edu/newcrop/m orton/lemon.html\#Culture.

3. Varies DP \& Dubois LAM (1990). Shoot production of "Sonia" on hybrid tea rootstock clones of different vigour. Gartenbauwissenschaft 55: 268-271.

4. Sharifani M, Akbarpour V, Zarrini SS \& Monfared AS (2010). Physical and chemical characteristics of 'Thompson Navel' orange fruits grown on four rootstocks in North of Iran. Am-Eura $J$ Agric \& Environ Sci 8(2): 156-160.

5. Wutscher HK (1979). Citrus rootstocks. Horticultural Review 1: 237-269.

6. Davies FS \& Albrigo LG (1998). Citrus. CAB International, Wallingford, UK.

7. Pinna \& Errea (2005). A review of new advances in mechanism of graft compatibility incompatibility. (Scientia Hort. 106: 1-11) and the resulting genetically composite organism functions as a single plant. 
8. Hartmann HT \& Beutel JA (1994). Propagation of temperate zone fruit plants Oakland, University of California, Division of agriculture and natural resources publication 21103.

9. Steel RGD, Torriea JH \& Dickey DA (1997). Principle and procedure of statistic. A biometrical approach, 3rd ED. McGraw Hill Book Co. Inc. New York. 172-177.

10. Sagar MKKR (2007). Propagation studies in cashew nut (Anacardium occidentalle L.) under mist house conditions. Dharwad: Department of Horticulture College of Agriculture, University of Agricultural Sciences.

11. Karadeniz $T$ (2005). Relationships between graft success and climatic values in walnut (Juglans regia L.). $J$ Centl Europ Agri 6: 631-634.

12. Chaudhary NA \& Ishfaq M (2004). Citrus and climate. In: Ahmad S (Ed.), Citrus fruit. The Horticultural Foundation of Pakistan, Islamabad, pp: 23-26.

13. Lee JM (1994). Cultivation of grafted vegetables I. Current status, grafting methods, and benefits. J Hort Sci 29: 240-244.

14. Rivero RM, Ruiz JM \& Romero L (2003). Role of grafting in horticulture plants under stress condition. $J$ Food Agric and Enviro 1: 70-74.

15. Zijlstra S, Groot SPC \& Jansen J (1994). Genotypic variation of rootstocks for growth and production in cucumber; Possibilities for improving by plant breeding. Sci Hort 56: 185-196.

16. Den-Nijs APM (1981). The effect of grafting on growth and early production of cucumbers at low temperature. Acta Hort 118: 57-64.
17. Niaz AC \& Chattha GA (1994). Characteristics of some local and exotic citrus rootstocks. $\mathrm{Pb} \mathrm{Fr} \mathrm{J} \mathrm{47(1-4):} \mathrm{22-}$ 29.

18. John AQ \& Paul TM (1999). Response of Chrysanthemum morifolium Ramat, to different levels of nitrogen and phosphorous. Applied Biological Research 1(1): 35-38.

19. Belgaonkar DV, Bist MA \& Wankade MB (1996). Effect of levels of nitrogen and phosphorus with different spacing on growth and yields of annual chrysanthemum. J Soil and Crop 6(2): 154-158.

20. Ridge I (1991). Plant Physiology. Hodder and Stoughon Educational Press. United Kingdom. Pp. 233.

21. Wareing PF \& Philips IDJ (1970). The Control of Growth and Differentiation in Plants. Pergamon Press, New York.

22. Mathad MC \& Nalwadi UG (1989). Rooting ability of some important ornamental climbers. South Indian Hort 37(5): 307-308.

23. Oda M, Tsuji K \& Sasaki H (1993). Effect of hypocotyl morphology on survival rate and growth of cucumbers seedlings grafted on cucurbita spp. Jap Agric Res Quart 26: 259-263.

24. Oda M, Dosia M, Ikeda H \& Furukawa H (2000). Causes of low survival in cucumber (Cucumis sativus) plants grafted on to pumpkin (Cucurbita moschata) rootstocks by horizontal-cut grafting at the center of the hypocotyls. Sci Res Agric Biol Sci Osaka Pref Univ 53: 1-5.

25. Izadi Z, Zarei H \& Alizadeh M (2014). Effect of time, cultivar and rootstock on success of rose propagation through stenting technique. Ameri J Plant Sci 5: 1644-1650. 